Vol. 1, No. 1, pp. 13-27, (October 2020)

Aswan University Journal of Environmental Studies (AUJES)

Online ISSN: 2735-4237, Print ISSN: 2735-4229

Journal homepage: http://aujes.aswu.edu.eg/

Review article

\title{
Role of organic and biofertilizers in citrus orchards
}

\author{
Abobatta W.F.* and El-Azazy A.M. \\ Agriculture Research Center, Horticulture Research Institute, Citrus department, Giza, Egypt.
}

Received: $25 / 8 / 2020$

Accepted: 15/9/2020

(C) Unit of Environmental Studies and Development, Aswan University

\begin{abstract}
:
Citrus trees (Citrus spp.) considered one of the major fruit worldwide, due to continuous and excessive use of synthetic fertilizers, there is a severe hazard to human health and to environment. The integrated fertilizing system in citrus orchards contributes to improve crop production through eco-friendly nutrient supply, producing healthy fruits, enhancing the plant tolerance to biotic stresses, increases growers' profits, and sustains natural resources. There are numerous types of organic fertilizers used in citrus orchards include Compost, Vermicompost, Humic substances, Biochar, Farm manure, and, microorganisms in biofertilizers increase the amount and availability of essential elements to plant, there are various biofertilizers used for different purposes according to the role of microorganisms like Nitrogen-fixing microorganisms like Azotobacter, Azospirillum, Rhizobium and Frankia; Phosphorous solubilizing microbes such as Pseudomonas and Bacillus; Phosphorous mobilizing as Vascular arbuscular mycorrhiza, and Plant growth promoting rhizobacteria (PGPR). There are numerous beneficial effects of organic and biofertilizers include increasing availability of nutrients in soils, increase the tree productivity, enhancing fruit quality, improve soil properties, stimulate microflora population in the rhizosphere, reducing the harmful effects of pathogenic organisms, and improving plant tolerance to biotic and abiotic stresses, particularly using both organic and biofertilizers play a critical role in environmental conservation, they can compensate large amounts of inorganic, fertilizer, reducing the great amount of inorganic fertilizer used indiscriminately in citrus orchards. Using a consortium of organic and biofertilizers with mineral fertilizers provide a positive response in citrus orchards.
\end{abstract}

Keywords: Citrus, Organic fertilizers, Biofertilizers, yield, fruit quality.

\section{1- Introduction}

Citrus considered being one of the most popular and favorite fruit worldwide, there are five common citrus species C. sinensis (sweet orange), C. limon (lemon), C. aurantifolia (lime) C. paradisi (Grapefruit) and C. reticulata Mandarin, (Rouiss, et al., 2017). Citrus is one of the most important fruit crops in tropical and subtropical countries. (FAO, 2017).

Corresponding authors*: E-mail addresses: wabobatta@yahoo.com 
Fertile soil considered a basic requirement for citrus cultivation, and, with the extension of citrus cultivation particularly in sandy soil, and the continuous use of inorganic fertilizers for prolonged periods to compensate the used nutrients, leading to the deterioration of soil physical and chemicals characteristics particularly fertility thereby limiting the organic matter in the soil, more attention for using organic and biofertilizers arise , as there is a strong relationship between soil organic matter content and citrus productivity (Ge et al., 2018). Due to rapid increase of world population which expected reach to 9 billion by 2050 and 12 billion by 2100, there is dramatic increase of food and agricultural commodities demands more than available production (FAO, 2017), so, the greatest potintial to fulfill this gap is to increase the productivity per unit area of cultivated land which may achiveded by, enhancing soil fertility through the use of alternate fertilizers as organic and biofertilizers along with chemical nutrients, in the same time horticultural production is facing various threats like challenges of climate change and increase environmental pollution (Abobatta, 2020), moreover, chemical fertilizers cause series environmental problems, as loss of soil nutrients, soil degradation, and reducing beneficial microorganisms (Suhag, 2016).

Organic and bio-fertilizers such as compost, vermicompost, biochar, humic substances, farm yard manure (FYM), azotobacter, azospirillum, vascular arbuscular mycorrhiza (VAM), plant growth-promoting rhizobacteria (PGPR), are being an essential component of nutrient management for all crops, on one hand, they improve the soil biodiversity which is very important to preserve soil health, and improve root growth due to change in the rhizosphere and microclimate of the plants, on the other hand, organic and biofertilizers could use as an alternative for pesticides in the integrated pest management system. There are various benefits of biofertilizers as they increase supplement of various nutrients, eco Friendly, cost-effective, improve fruit quality, and help plant to tolerate stress conditions (Ortaş, 2012). Using organic and bio fertilizers considered a key tool for sustainable horticulture crop production system, it offers improving soil health, increasing crops, and enhancing fruit quality, minimizing costs, and sustains natural resources (Hazarika and Aheibam, 2019). Organic and Biofertilizers must be a part of the integrated fertilizing system with synthetic fertilizers to improve the soil characters and sustain horticultural crop productivity (Pathak et al., 2017). Furthermore, the combination of organic and biofertilizer, causes a slow release of nitrogen needed for nutrition during fruit growth period causing an increase in fruit size moreover higher uptake of water and nutrients as potassium due to the biofertilizer, lead to increase of water content in peel and pulp (Debnath et al., 2019). This work aims to explore the effect of nutrient management through bio fertilizers and organic fertilizers on growth and productivity of citrus orchards, but more research is required to determine the proper combination of organic and biofertilizers in association with mineral fertilizers to maximize production, enhancing fruit quality, and sustain the environment (Martinez-Alcantara et al., 2016).

\section{Synthetic Fertilizers:}

Due to imbalanced use of these fertilizers, there are different problems such as losing soil fertility, contamination of groundwater, and environmental pollution result, which in turn reflects on the crop, therefore, there is a need for developing alternate more judicious fertilizers that are improving horticultural production, sustain soil health and eco-friendly (Wong et al., 2015). 


\section{Hazard effects of synthetic fertilizers:}

The indiscriminate use of synthetic fertilizers for many decades leds to negative impacts on crops and environment (Bankole, et al. 2019; Pindi and Satyanarayana 2012), including:

1. Pollution and contamination of the soil and groundwater.

2. Demolish rhizosphere micro-organisms and friendly insects.

3. Reduce soil fertility

4. Affect negatively plant health, and become more suspect to pathogens.

\section{Why we need organic and biofertilizers in horticultural orchard?}

There are numerous efforts to optimize the inputs of organic and biofertilizers in citrus cultivations as shown in Table 1 like improving plant growth and productivity, increasing plant tolerance to various abiotic stress such as drought, high temperature, and salinity (MoruganCoronado et al. 2020), also, organic fertilizers enhance plant health to tolerate biotic stress like Citrus Leafminer (Phyllocnistis citrella) damage, citrus canker infection (Ullah et al. 2019), and nematodes (Abd-Elgawad, 2020), it could be an important aspect in the integrated management program for citrus orchards.

They are found to be useful for different horticultural crops for integrated fertilizing system. According to previous research, there is more attention for healthy fruit crop production particularly Citrus (Aji, 2020).

\section{Organic fertilizers and horticultural orchared:}

In comparison to synthetic fertilizers, the organic fertilizers may be more effective to induce plant vigor, increase the ability of plants to tolerate biotic and abiotic threats, and enhancing fruit quality (Ullah et al., 2019), using organic fertilizers improving soil health, enhancing soil physical and chemical properties, increasing the productivity of the citrus, produces healthy fruits devoid chemical residues thereby safer for human health, and fetches the higher value for crops (Hameed et al., 2018). There are various beneficial effects of organic fertilizers on soil and crop such as:

1. Increasing water holding capacity.

2. Improving soil buffering capacity.

3. Enhancing the availability of nutrients.

4. Releasing plant growth-stimulating hormones.

5. Reducing the damage caused by pathogen/pest.

6. Improving tolerance to abiotic stress.

\section{Citrus and organic fertilizers:}

Citrus needs eco-friendly fertilizers to increase their efficiency of production, so, the application of organic fertilizers providing an economical attention for reducing external inputs of synthetic agrochemical and sustaining the natural resources (El-Badawy, 2017), therefore, organic fertilizers use in citrus orchard as a part of a production system that avoids or largely excludes the use of synthetic chemical fertilizers to produces healthy fruits. From another side, developing liquid organic fertilizers considered an excellent tool for improving citrus growth and sustain soil health, increasing microorganisms' vitality (Martinez-Alcantara et al., 2016). 
Aswan University Journal of Environmental Studies (AUJES) 1 (1), pp. 13-27, (2020).

Online ISSN: 2735-4237, Print: ISSN 2735-4229. http://aujes.aswu.edu.eg/

Table 1. Influence of organic and biofertilizers on citrus cultivation

\begin{tabular}{|c|c|c|c|c|}
\hline \multirow{2}{*}{ No. } & Bio-agent & \multirow{2}{*}{ Citrus species } & \multirow{2}{*}{ Response } & \multirow{2}{*}{ Reference } \\
\hline & Organic fertilizer & & & \\
\hline \multirow{2}{*}{1} & VAM and Azotobacter & \multirow{2}{*}{$\begin{array}{l}\text { Sweet Orange } \\
\text { (Citrus sinensis L.) }\end{array}$} & \multirow{2}{*}{$\begin{array}{l}\text { Increasing productivity and } \\
\text { enhancing fruit quality }\end{array}$} & \multirow[t]{2}{*}{ Rana et al. (2020) } \\
\hline & FYM & & & \\
\hline \multirow{2}{*}{2} & & \multirow{2}{*}{$\begin{array}{l}\text { Satsuma mandarin } \\
\text { (Citrus unshiu) }\end{array}$} & \multirow[t]{2}{*}{ Improving fruit quality } & \multirow[t]{2}{*}{ Wu, et al. (2020) } \\
\hline & Biochar & & & \\
\hline \multirow[t]{2}{*}{3} & $\begin{array}{l}\text { Lactobacillus,Saccharomyces } \\
\text { Rhodopseudomonas }\end{array}$ & \multirow[t]{2}{*}{$\begin{array}{l}\text { Murcott tangerine } \\
\text { (Citrus reticulata) }\end{array}$} & \multirow{2}{*}{$\begin{array}{l}\text { Increase tree productivity } \\
\text { and improve leaf mineral } \\
\text { content }\end{array}$} & \multirow[t]{2}{*}{ Fikry et al. (2020) } \\
\hline & Chicken manure & & & \\
\hline \multirow{2}{*}{4} & Azotobacter, PSB, and VAM & \multirow{2}{*}{$\begin{array}{l}\text { Acid lime (Citrus } \\
\text { aurantifolia Swingle) }\end{array}$} & \multirow[t]{2}{*}{ Implement fruit quality } & \multirow{2}{*}{$\begin{array}{l}\text { Kumar et al. } \\
(2020)\end{array}$} \\
\hline & FYM, Vermi-compost & & & \\
\hline \multirow[b]{2}{*}{5} & & \multirow{2}{*}{$\begin{array}{l}\text { Valencia orange } \\
\text { (Citrus sinensis L) }\end{array}$} & \multirow{2}{*}{$\begin{array}{l}\text { Increasing vegetative growth } \\
\text { and decreasing incidence of } \\
\text { disease }\end{array}$} & \multirow{2}{*}{$\begin{array}{l}\text { Tadayon and } \\
\text { Hosseini, (2020). }\end{array}$} \\
\hline & Compost as organic mulch & & & \\
\hline \multirow{2}{*}{6} & & \multirow{2}{*}{$\begin{array}{l}\text { Volkamer lemon } \\
\text { (citrus volkameriana) }\end{array}$} & \multirow[t]{2}{*}{ Improving vegetative growth } & \multirow[t]{2}{*}{ Ihsan et al. (2019) } \\
\hline & Humic and fulvic acid & & & \\
\hline \multirow[b]{2}{*}{7} & Azotobactor, and VAM & Acid lime & Improve vegetative growth, & Bhandari et \\
\hline & FYM and Vermi-compost & (Citrus aurantifolia) & $\begin{array}{l}\text { increasing productivity and } \\
\text { fruit quality. }\end{array}$ & al.(2018) \\
\hline & & kinnow mandarin & Increasing vegetative & Hameed et \\
\hline 8 & Humic acid & & $\begin{array}{l}\text { growth, improving leaf } \\
\text { mineral content and } \\
\text { improving fruit quality. }\end{array}$ & \\
\hline 0 & Biofertilizers & Valencia orange & Increasing productivity and & El-Badawy, (2017) \\
\hline 9 & Compost & (Citrus sinensis) & leaf mineral content. & \\
\hline 10 & Azotobacter and VAM & Lemon (Citrus limon) & Enhancing fruit quality & Ghosh et al. \\
\hline 10 & Vermi-compost & & & (2017) \\
\hline 11 & Azotobacter & Lemon (Citrus limon) & Improving fruit quality & Khehra and Bal, \\
\hline 11 & FYM & & & $(2016)$ \\
\hline 12 & & (Poncirus trifoliata) & Enhancing root growth & Changxu et \\
\hline 12 & Biochar & & & al.(2016) \\
\hline & VAM, PSP, and Azospirillum & Nagpur mandarin & Increase tree productivity, & Hadole et al. \\
\hline 13 & & (Citrus eticulata) & $\begin{array}{l}\text { fruit quality, and improving } \\
\text { leaf mineral content }\end{array}$ & (2015) \\
\hline & & Valencia late & Improving root growth & Trinchera, et \\
\hline 14 & $\begin{array}{l}\text { Compost - poultry manure - } \\
\text { bovine }\end{array}$ & (Citrus sinensis) & $\begin{array}{l}\text { Improving soil fertility and } \\
\text { quality }\end{array}$ & al.(2015) \\
\hline & VAM & Orange & Increasing vegetative growth & Xiao et al. (2014) \\
\hline 15 & & $\begin{array}{l}\text { (Citrus sinensis) } \\
\text { Mandarin } \\
\text { (Citrus reticulate) }\end{array}$ & $\begin{array}{l}\text { and improving leaf mineral } \\
\text { content }\end{array}$ & \\
\hline & Pseudomonas fluorescens & Navel orange & Increase tree productivity and & Shamseldin et al. \\
\hline 16 & & (Citrus sinensis) & $\begin{array}{l}\text { improving leaf mineral } \\
\text { content }\end{array}$ & $(2010)$ \\
\hline 17 & $\begin{array}{l}\text { VAM, Azotobacter, } \\
\text { Azospirillum, } \\
\text { Bacillus circulans }\end{array}$ & $\begin{array}{l}\text { Balady mandarin } \\
\text { (Citrus reticulata) }\end{array}$ & $\begin{array}{l}\text { Increase tree yield and } \\
\text { improving leaf mineral } \\
\text { content }\end{array}$ & $\begin{array}{l}\text { Aiman et al. } \\
(2009)\end{array}$ \\
\hline
\end{tabular}

*Vesicular-arbuscular mycorrhiza (VAM) - *Phosphate Solubilizing Bacteria (PSB)

*Farm yard manure FYM 
Different roles of organic fertilizers in citrus orchards include:

1. Promote the uptake of numerous macro and micronutrients.

2. Enhance biomass production in citrus plants.

3. Stimulating microflora population in the rhizosphere.

4. Provides sites for the microflora to use various bacterial secreting enzymes.

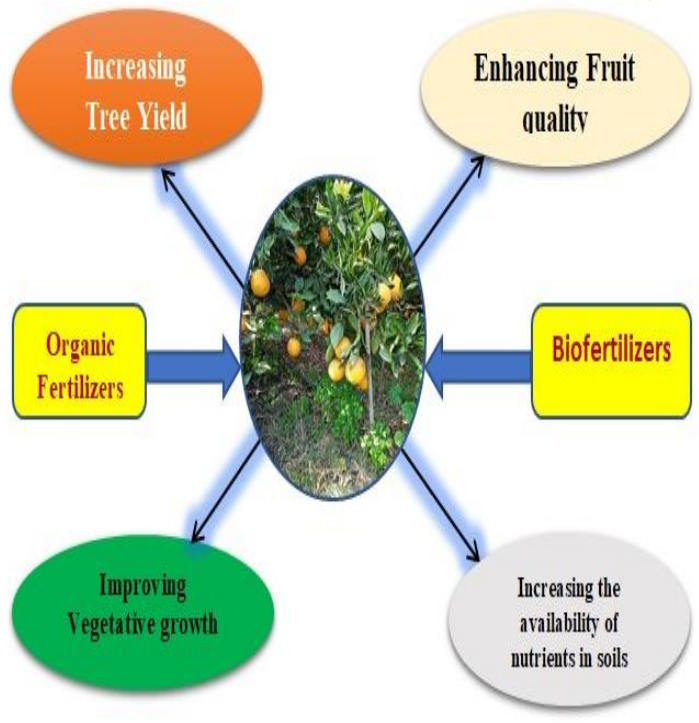

Figure 1: Main Influences of Organic and Biofertilizers on Citrus Tree

There are numerous benefits of organic and bio fertilizers in citrus production (Figure 1) include improving fruit quality, increasing availability of nutrients in soil, reducing pollution, and preserve ecological balance, therefore, using organic fertilizers in citrus orchards will help in safeguarding the soil and enhancing the quality of production, which offers economically sustainable profits. Thereby, organic fertilizers represent a part of the efforts that have been executed for increasing the production of citrus and protect the environment (Martinez-Alcantara et al., 2016).

\section{Types of organic fertilizers:}

There are various organic fertilizers including compost, vermicompost, farmyard manure, biochar and humic substances.

\section{Compost}

It is one of the oldest organic fertilizers, which use to preserve nutrients in natural wastes and returned the macro and micronutrients to the soil. The composting process producing stable humus, humic, and fulvic acids, so, compost has high nutritional value, particularly under nutrient deficiency conditions. There are numerous physical, chemical, biological, or environmental nature benefits for using compost as a part of the integrated fertilization system (Pardo et al., 2017).

According to previous researches, the annual soil application of compost to citrus orchards improve tree growth and increasing productivity, Tadayon and Hosseini (2020) reported that, adding compost to Valencia orange orchard soils improve tree growth and reduce citrus decline amelioration; improve Valencia orange yield and fruit quality, moreover, compost application improve "Rio Red" grapefruit production under integrated fertility management plan 
(Nelson, et al., 2008) and El-Badawy (2017) furthermore, organic fertilizers, enhance soil organic matter, and improve root biomass in "Valencia late" trees [Citrus sinensis (L) Osbeck],Trinchera, et al.. (2015).

There are different benefit for compost applications in citrus orchards include:

1) Increasing tree productivity and fruit yields.

2) Stimulating tree growth.

3) Enhancing soil penetrability.

4) Improving economic benefits for citrus growers

\section{Vermicompost}

Vermicompost the most organic fertilizers peat-like materials, produced from various organic materials by composting process using defined species of earthworms (Ramnarain et al., 2019), Also, Vermicompost is made of finely divided particals, contains numerous nutrients in available forms it has beneficial characters as high porosity, microbial activity, good aeration and drainage, increase water holding capacity, remarkable nutrient status and buffering capacity (Pathma and Sakthivel. 2012) (Piya et al., 2018), in addition vermicompost, promote beneficial microbes, provide different microsites for microorganisms and, so enhancing soil biodiversity which consecuantly improve plant growth, and it's rich in various microbial populations like fungi, bacteria and actinomycetes (Lim et al., 2015).

\section{Benefits of Vermicompost:}

There are numerous positive impacts for vermicompost on soil structure and plant growth includes:

1. Enhancing soil physiochemical characters such as aggregation, stability, $\mathrm{pH}, \mathrm{EC}$, bulk density, and water holding capacity.

2. Amplified soil stability, increase organic matter, and minimized soil degradations.

3. Improving biological properties (microorganism population and enzymes).

4. Increase nutrients availability for plants

5. Improve plant growth

6. Increasing plant tolerance for various stress types.

\section{Farm yard manure (F Y M):}

Farm yard manure (F Y M) has been widely used from ancient time for soil fertilization, animal manure is reaching with nutrients like nitrogen $(\mathrm{N})$ and potassium $(\mathrm{K})$, medium proportions of calcium $(\mathrm{Ca})$ and phosphorus $(\mathrm{P})$, and low quantities of magnesium $(\mathrm{Mg})$ and sulfur (S) (Francioli et al, 2016).

There are different benefits for manure such as:

- Improving soil physicochemical properties.

- Enhancing the beneficial microbial populations.

- Manure increases organic matter in the soil.

- Increase the availability of nutrients to plants.

There are some cautions before using manure like:

- The manure must add to the soil by acceptable quantities.

- Recommended using manure after crop harvest during cool weather.

- It is preferable to spread manure in a thin layer over a large surface area around the trees. 


\section{Biochar:}

According to Kavitha et al.(2018) Biochar is a stable carbon-based solid produced from pyrolysis of biomass under anaerobic conditions, Biochar properties varying depending on pyrolysis conditions, ash content, and raw materials (Agegnehu et al., 2015), from one hand, Carbon (C) in biochar is more steady and after adding to soil, this $(\mathrm{C})$ remains reserved for long periods than other (C) forms, On the other hand, the benefits of biochar in ameliorating soil $\mathrm{pH}$ have attracted increasing interest in citrus industries (Wu et al. 2020) and (Guo et al., 2016).

\section{Role of Biochar:}

Biochar acting as a promising soil amendment, which can improve soil physicochemical characters, promote plant growth, enhancing soil organic carbon content, increasing water holding capacity, and ameliorate soil pollution (Jeffery et al. 2011).

There is a wide range of agricultural benefits for Biochar as follow:

a) Extending carbon sequestration in soil. (Purakayastha, et al. 2015).

b) Increase soil capacity to preserve water and nutrient (Tayyab, et al. 2018); (Kizito et al. 2019).

c) Improvement of soil characters particularly fertility (Ding, et al. 2016).

d) Enhancing plant resistance to pathogens (Burketova et al. 2015).

e) Reducing gas emission from soil mainly nitrous oxide (Singh etal. 2010).

While using biochar in citrus orchards could provide numerous positive effects include:

a) Improving growth of trifoliate seedling (Changxun et al. 2016).

b) Enhancing fruit quality of Satsuma mandarin (Wu et al. 2020).

c) Increasing nutrient supply (Khan et al. 2020).

\section{Liquid organic fertilizer:}

Liquid organic fertilizer produce from various natural origins materials, liquid organic fertilizers used by small doses, and their effect faster in sustain soil and improve plant growth compare to solid organic fertilizers. The use of liquid organic fertilizer could be used as a foliar application through tree canopy or soil surfaces or in fertigation system to optimize the effects of solid organic fertilizer on growth and yields of trees, currently, there are more interesting to use humic substances, Fulvic acid, and biochar in citrus cultivation (Martínez-Alcantara et al.,2016).

\section{Humic Substances (HS):}

Humic substances (HS) considered a key component of soil and affect positively various rhizosphere properties (chemical, physical, and biological). Humic substances have numerous positive effects on the soil due to carboxyl, hydroxyl, amide, and other hydrophilic groups, which work as chelating nutrients and improve soil cation exchange, also due to variable proportions that modify soil properties like holding water, $\mathrm{pH}, \mathrm{EC}$, and soil penetration, particularly in heavy clay soil. Several previous literatures showed a continuing enhancing in the vegetative growth parameters includes (trunk circumference, tree canopy volume, and leaf area), increase tree yield, and improving fruit quality combined with regular application of humic substances, Al-Kraawi et al, (2020) on Lemon citrus (Citrus limon [L.] Burm); Ihsan et al. (2019) on Volkameriana seedlings; Hameed et al. (2018) on kinnow mandarin (Citrus reticulata); Maidan and Maree (2018) on orange (Citrus sinensis L.); Al-Hayani (2016) on lemon; Abobatta (2015) on Valencia orange (Citrus sinensis L.). 


\section{Biofertilizer:}

Biofertilizers are beneficial microbial inoculants containing one or more species of specific microorganism derived from rhizosphere, it could use as a partial alternative for soluble fertilizers, they are economically and ecosystem friendly, as showing in figure (1) usage of biofertilizers in citrus orchards can be a possible alternative way to enhance vegetative growth, increase tree productivity, produce safety fruits, improving plant tolerance to abiotic stress, reduce infection by pathogens besides improve the soil fertility, reduce costs, sustain soil and reducing environment contamination (Shamseldin et al., 2010).

Biofertilizers are classified into four main groups:

1. Nitrogen-fixition

2. Phosphorous solubilizing

3. Biofertilizers for Micronutrients

4. Growth Promoting Rhizobacteria

The advantages of biofertilizers: according to previous researches like Yadav and Sarka (2019); (Pathak et al., 2017); and (Hanin et al., 2016) there are numerous benefits of biofertilizers include:

1. Improve soil physical and chemical characters and maintain soil sustainability

2. Enrichment soil microflora.

3. Reducing environmental degradation.

4. Increasing the availability of nutrients.

5. Increasing crop production

6. Releasing plant growth-stimulating hormones,

7. Improving plant tolerance to various stresses.

\section{Citrus and Biofertilizers:}

\section{Nitrogen fixing:}

a. Free-living bacteria (nonsymbiotic) such as Azotobacter

b. Associative Symbiotic as Azospirillum

c. Symbiotically like Rhizobium and Frankia

Nitrogen-fixing organisms are microbial inoculants that can fix atmospheric nitrogen and transform it into organic nitrogenous compounds used by plants. They play an important role in enhancing cell division and cell enlargement through induce releasing of growth hormones, which reflected in increasing yield and improve fruit quality. Currently, Nitrogen-fixing microorganisms get great attention from citrus growers due to its role in reducing the quantity of inorganic nitrogen fertilizer which reflected in reducing costs, enhancing fruit quality (Khehra and Bal 2016) on (Citrus limon (L.) Burm.) cv. Baramasi; increase tree yield of sweet orange (Citrus sinensis L.) cv. Mosambi (Rana et al., 2020); (Shaimaa, and Massoud 2017) on Washington navel orange (Citrus sinensis [L.] Osbeck); and Bhandari et al., (2018) on Acid lime (Citrus aurantifolia Swingle); reduced nitrate and nitrite residue in fruit juice of Washington navel orange (El-Migeed et al., 2007).

\section{Phosphorous solubilizing microbes (PSM):}

Phosphorous solubilizing microbes (PSM) such as Pseudomonas and Bacillus, hydrolysing insoluble phosphorus compounds to soluble form that can be assimilated easily by plants, provides an environmentally, economically and good approach to overcome the $\mathrm{P}$ deficiency. Inoculation citrus orchards with PSM enhancing tree growth, yield, and fruit quality 
(Maklad, and Elkhawaga 2013), increase availability of the soluble form of P to uptake by roots, also stimulates the production of plant growth hormones as IAA and GA3 (Saleemi et al. 2017) also, increases the efficiency of nitrogen fixation (Kalayu 2019).

\section{Phosphorous mobilizing:}

It has been disclosed that hyphae of vascular arbuscular mycorrhiza (VAM) exhibited greater fungal actions on citrus growth and nutrient uptake, citrus plants are strongly dependent on mycorrhizal (Abobatta 2019). VAM inoculation enhances citrus plant tolerance against stress conditions by increasing nutrient uptake and improves the transport of water to host plants, consequently enhanced plant growth (Vives-Peris et al., 2018a), also, inculcation of Poncirus trifoliata (L.) seedlings with VAM increase growth parameters like plant height, leaf numbers, stem diameter, and dry matter, also, could reduce symptoms of iron-chlorosis through stimulating $\mathrm{Fe}+++$ chelate reductase enzyme in root and accumulation of total iron and active iron in leaves (Wang and Xia 2009).

\section{Plant growth-promoting rhizobacteria (PGPR):}

Plant growth promoting rhizobacteria (PGPR) are group of useful microorganisms that occupied rhizosphere and they belong to many genera of bacteria as Bacilli, Enterobacter, and Pseudomonas (Ramezani et al., 2015).

PGPR categorized according to their effects on plants as follow:

1. Biofertilizer: biofertilizer bacteria enhance plant growth through different mechanisms as increase mobilization of insoluble nutrients, improve solubilization of some element in the rhizosphere as phosphorus and Zinc, or produce phytohormones as cytokinins and auxins in the rhizosphere (Martinez-Viveros et al., 2010).

2. Biopesticides: whereas rhizobacteria inhibit the growth of pathogenic organisms like bacteria, fungi, and nematodes by antagonistic effect through producing hydrolytic enzymes and antibiotics (Wong et al, 2015); Martinez-Viveros et al., 2010).

\section{Role of organic and biofertilizers under abiotic stress conditions:}

Organic and Biofertilizers play a key role in improving various soil characters and enhance stress tolerance in citrus, from one hand, there is a strong relationship between soil fertility and organic fertilizers through increasing the soil organic matter of sandy soil and degraded soils, which boost citrus productivity, enhance soil microbial growth and activities, improve water holding capacity, and enhancing buffering capacity, from other hand, biofertilizers inoculation enhance stress tolerance in citrus, as inoculation of Citrus macrophylla with two PGPR, Pseudomonas putida and Novosphingobium sp. alleviate salt stress damage under salinity conditions ,by reducing abscisic acid (ABA) and salicylic acid (SA) levels , and increase 3-indole acetic acid (IAA) level in Citrus macrophylla leaves, also, Pseudomonas putida inhibited accumulation of chloride and proline in root under salt stress conditions (Vives-Peris et al., 2018 b), besides that, PSM acts as a biocontrol against pathogenic organisms by the production of antibiotics, antifungal metabolites, and hydrogen cyanate (HCN) (Kalayu 2019).

\section{Conclusion:}

The application of organic and biofertilizers have a vital role in improving citrus orchards productivity, enhancing fruit quality, and increasing the availability of nutrients in soils, in addition to providing economic impacts for reducing external inputs of the synthetic 
agrochemical, and sustaining the natural resources. Organic and Biofertilizers must be a part of the integrated fertilizing system as partial supplemented for inorganic fertilizers to sustain citrus productivity, increase citrus tolerant for biotic and abiotic stresses, and preserves soil health.

\section{Abbreviations:}

FAO: Food and Agriculture Organization; FYM: Farm yard manure; VAM: Vascular arbuscular mycorrhiza; PGPR: Growth Promoting Rhizobacteria; (C): Carbon; PSM: Phosphorous solubilizing microbes, Abscisic acid; ABA:salicylic acid ;SA: levels , and Indole acetic acid ;IAA.

\section{References:}

Abd-Elgawad, M. M. (2020). Managing nematodes in Egyptian citrus orchards. Bulletin of the National Research Centre, 44, 1-15.

Abobatta, W. F. (2020). Citriculture and Climate Change. Agrono. 6(3). MCDA. 000639. 2020. DOI: 10.31031/MCDA.2020.06.000639

Abobatta, W.F. (2019). Arbuscular Mycorrhizal and Citrus growth. Acta Scientific Microbiology, 2(6): 14-17.

Abobatta W.F. (2015). Influence of Magnetic Iron and K-Humate on Productivity of Valencia Orange Trees (Citrus Sinensis L.) under Salinity Conditions. International Journal of Scientific Research in Agricultural Sciences, 2(Proceedings), pp. 108-119, 2015 Available online at http://www.ijsrpub.com/ijsras.

Aiman, K.A. Mohamed, Z., Mohamed, M. M. A. and Mohamed. M. E. (2009). Is it Possible to Compensate the Annual Fertilization in Mandarin Orchards by Using the Bio-fertilizers. Assiut J. of Agric. Sci., 40 (4): 37-68.

Al-Hayani, A.M.A. (2016). The effect of origin and spraying with humic acid on tolerance of sour lemon saplings to salinity in irrigation water and characteristics of vegetative growth. Basra Journal of Agricultural Sciences, 29(2): 485-501.

Al-Kraawi, A. A., Al-Abbasi, G. B. and Alabbasi, F. S. (2020). Effect of spraying with Potassium humate and Azoren Mix on growth traite and nutrients content of local lemon Citrus limon saplings. Plant Archives, 20(2): 574-577.

Agegnehu, G., Bass, A. M., Nelson, P. N., Muirhead, B., Wright, G. and Bird, M. I. (2015). Biochar and biochar-compost as soil amendments: effects on peanut yield, soil properties and greenhouse gas emissions in tropical North Queensland, Australia. Agriculture, ecosystems \& environment, 213: 72-85.

Aji, T. G. (2020). Nutrition management in conversion-to-organic citrus orchard in the Indonesian citrus and subtropical fruits research institute. In IOP Conference Series: Earth and Environmental Science, 484(1), p. 012057). IOP Publishing.

Bankole, S., O., Akala, A., O. and Adegboyega, D., A. (2019). Potential Significance of Beneficial Microbes for Sustainable Soil Management and Plant Utilization. Acta Scientific Microbiology 2.6: 88-95. 
Bhandari,J. Kanpure, R.N., Singh, O.P., Kachouli, B. and Patidar, D.K. (2018). Effect of organic and inorganic nutrient sources on growth, yield and quality of Acid lime (Citrus aurantifolia Swingle). International Journal of Chemical Studies, 6(1): 1635-1639

Basso, A. S., Miguez, F. E., Laird, D. A., Horton, R. and Westgate, M. (2013). Assessing potential of biochar for increasing water-holding capacity of sandy soils. Gcb Bioenergy, 5(2), 132-143.

Burketova, L., Trda, L., Ott, P., and Valentova, O. (2015). Bio-based resistance inducers for sustainable plant protection against pathogens. Biotechnology advances. 33: 994-1004.

Changxun, G., Zhiyong, P. and Shu'ang, P. (2016). Effect of biochar on the growth of Poncirus trifoliata (L.) Raf. seedlings in Gannan acidic red soil. Soil Science and Plant Nutrition, 62(2):194-200.

Debnath, S, Rawat, D., Mukherjee, A., Adhikary, S. and Kundu, R. (2019). Applications and Constraints of Plant Beneficial Microorganisms in Agriculture. 10.5772/intechopen.89190.

Ding, Y., Liu, Y., Liu, S., Li, Z., Tan, X., Huang, X., Zeng, G. Zhou, L. and Zheng, B. (2016). Biochar to improve soil fertility. A review. Agronomy for Sustainable Development. 36(2):1-18. 10.1007/s13593-016-0372-z.

El-Badawy, H. E. M. (2017). Partial substitution of Valencia orange chemical fertilization by bioorganic fertilization conjoint with algae extract foliar spray. Middle East Journal of Applied Sciences, 7(4): 1016-1030.

El-Migeed, M.M.M, Saleh, M. and Mostafa, E.A.M. (2007). The beneficial effect of minimizing mineral nitrogen fertilization on Washington navel orange trees by using organic and biofertilizers. World Journal of Agricultural Sciences, 3:80 - 85.

Fikry, A. M. , Abou Sayed Ahmed, T.A.M., Mohsen, F.S. and Ibrahim, M.M. (2020). Effect of Nitrogen fertilization through inorganic, organic and biofertilizers sources on vegetative growth, yield and nutritional status in Murcott Tangerine trees. Plant Archives, 20 (1):1859-1868.

FAO. (2017). The future of food and agriculture - Trends and challenges. Rome. http://www.fao.org/3/a- i6583e.pdf

Francioli, D., Schulz, E., Lentendu, G., Wubet, T., Buscot, F. and Reitz, T. (2016). Mineral vs. organic amendments: microbial community structure, activity and abundance of agriculturally relevant microbes are driven by long-term fertilization strategies. Frontiers in microbiology, 7, 1446.

Ge, S., Zhu, Z. and Jiang, Y. (2018). Long-term impact of fertilization on soil pH and fertility in an apple production system. Journal of Soil Science and Plant Nutrition, 18 (1): 282-293.

Ghosh, A., Dey, K., Bhowmick, N., Ghosh, S., Bandyopadhyay, S., Medda, P. and Ghosh, A. (2017). Lemon Cv. Assam Lemon (Citrus limon Burm.) Quality and Soil-Leaf Nutrient Availability Affected by Different Pruning Intensities and Nutrient Management. Current Science. 112. 2051. 10.18520/cs/v112/i10/2051-2065. 
Guo, C., Pan, Z. and Peng, S. (2016). Effect of biochar on the growth of Poncirus trifoliata (L.) Raf. seedlings in Gannan acidic red soil. Soil Sci. Plant Nutr. 62: 1-7.

Gupta, G., Srivastava, S., Khare, S. and Prakash, V. (2014). Role of phosphate solubilizing bacteria in crop growth and disease management. Journal of Pure and Applied Microbiology. 8: 461-474.

Hadole, S.S., Waghmare, S. and Jadhao, S. D. (2015). Integrated use of organic and inorganic fertilizers with bioinoculants on yield, soil fertility and quality of Nagpur mandarin (Citrus reticulata Blanco). International Journal of Agricultural Sciences. 11: 242-247. 10.15740/HAS/IJAS/11.2/242-247.

Hameed, A., Fatma, S., Wattoo, J. I., Yaseen, M. and Ahmad, S. (2018). Accumulative effects of humic acid and multinutrient foliar fertilizers on the vegetative and reproductive attributes of citrus (Citrus reticulata cv. kinnow mandarin). Journal of Plant Nutrition, 41(19): 24952506.

Hanin, M., Ebel, C., Ngom, M., Laplaze, L. and Masmoudi, K. (2016). New insights on plant salt tolerance mechanisms and their potential use for breeding. Frontiers in plant science, 7:117 https://doi.org/10.3389/fpls.2016.01787

Hazarika, T. K. and Aheibam, B. (2019). Soil nutrient status, yield and quality of lemon (Citrus limon Burm.) cv.'Assam lemon'as influenced by bio-fertilizers, organics and inorganic fertilizers. Journal of Plant Nutrition, 42(8): 853-863.

Ihsan, J., Laila, T. F. and Falah, H. A. (2019). Effect of organic fertilizer master humic-fulvic acid and salt clean on some chemical characteristics of soil and some vegetative characteristics of stock Volkameriana. Jornal of Al-Muthanna for Agricultural Sciences, 7(1): $1-8$.

Jeffery S., Verheijen F. G. A., Van Der Velde, M. and Bastos, A. C. (2011). A quantitative review of the effects of biochar application to soilson crop productivity using metaanalysis. Agric Ecosyst Environ, 144:175-187.

Kalayu, G. (2019). Phosphate Solubilizing Microorganisms: Promising Approach as Biofertilizers. International Journal of Agronomy, 7. 10.1155/2019/4917256.

Kavitha, B., Reddy, P. V. L., Kim, B., Lee, S. S., Pandey, S. K. and Kim, K. H. (2018). Benefits and limitations of biochar amendment in agricultural soils: A review. Journal of environmental management, 227: 146-154.

Khan, M. B., Cui, X., Jilani, G., Tang, L., Lu, M., Cao, X., Sahito, Z.A., Hamid, Y., Hussaine, B., Yang, X. and He, Z. (2020). New insight into the impact of biochar during vermistabilization of divergent biowastes: Literature synthesis and research pursuits. Chemosphere, 238: 124679.

Khehra, S. and Bal, J.S. (2016). Influence of combined use of organic, inorganic and biological sources of nutrients on fruit quality in lemon. International Journal of Agriculture, Environment and Biotechnology, 9. 85. 10.5958/2230-732X.2016.00013.9.

Kizito, S., Luo, H., Lu, J., Bah, H., Dong, R. and Wu, S. (2019). Role of nutrient-enriched biochar as a soil amendment during maize growth: exploring practical alternatives to 
recycle agricultural residuals and to reduce chemical fertilizer demand. Sustainability. 11(11):1-22.

Kumar, T.R., Kumar, G.P., and Kumar, R.S. (2020). Integrated use of organic and inorganic fertilizers with bio -inoculants on physicological characteristics of Acid Lime (Citrus Aurantifolia Swingle). Plant Archives, 20(1):1769-1772.

Lim, S. L., Wu, T. Y., Lim, P. N. and Shak, K. P. Y. (2015). The use of vermicompost in organic farming: overview, effects on soil and economics. Journal of the Science of Food and Agriculture, 95(6): 1143-1156.

Maidan, R.A. and Maree, R.S. (2018). The effect of adding NPK and humic acid on growth and chlorophyll content of seed orange Citrus sinensis L. trees. Journal of Kirkuk University of Agricultural Sciences. Special issue for the Third International Agricultural Conference. $352-257$

Maklad, M. and Elkhawaga, A. (2013). Effect of combination between Bio and chemical fertilization on vegetative growth, yield and quality of Valencia orange fruits. Journal of Suez Canal University, 1: 269-279.

Martínez-Viveros, O., Jorquera, M. A., Crowley, D. E., Gajardo, G. M. L. M. and Mora, M. L. (2010). Mechanisms and practical considerations involved in plant growth promotion by rhizobacteria. Journal of soil science and plant nutrition, 10(3): 293-319.

Martínez-Alcantara, B., Martínez-Cuenca, M. R., Bermejo, A., Legaz, F., and Quinones, A. (2016). Liquid organic fertilizers for sustainable agriculture: Nutrient uptake of organic versus mineral fertilizers in citrus trees. PLOS ONE, 11(10):1-20

Morugan-Coronado, A., Linares, C., Gomez-Lopez, M. D., Faz, A. and Zornoza, R. (2020). The impact of intercropping, tillage and fertilizer type on soil and crop yield in fruit orchards under Mediterranean conditions: A meta-analysis of field studies. Agricultural Systems, 178, 102736

Nelson, S. D., Uckoo, R. M., Esquivel, H., Enciso, J. M. and Jones, K. (2008). Compost Effects in "Rio Red" Grapefruit Production on a Heavy Textured Soil. Dynamic Soil, Dynamic Plant, 2:67-71.

Ortaş, I. (2012). Mycorrhiza in Citrus: Growth and Nutrition. Advances in Citrus Nutrition. 333351. 10.1007/978-94-007-4171-3_23.

Pardo, G., Del Prado, A., Martínez-Mena, M., Bustamante, M. A., Martín, J. R., Alvaro-Fuentes, J. and Moral, R. (2017). Orchard and horticulture systems in Spanish Mediterranean coastal areas: Is there a real possibility to contribute to $\mathrm{C}$ sequestration?. Agriculture, Ecosystems \& Environment, 238: 153-167.

Pathak, D.V., Kumar, M., and Rani, K. (2017). Biofertilizer Application in Horticultural Crops. In Microorganisms for Green Revolution; Springer: Berlin/Heidelberg, Germany, pp. 215227.

Pathma, J. and Sakthivel, N. (2012). Microbial diversity of vermicompost bacteria that exhibit useful agricultural traits and waste management potential. Springer Plus, 1, 26. https://doi.org/10.1186/2193-1801-1-26. 
Piya, S., Shrestha, I., Gauchan, D. P. and Lamichhane, J. (2018). Vermicomposting in organic agriculture; Influence on the soil nutrients and plant growth. International Journal of Research, 5:1055-1063.

Pindi, P. K. and Satyanarayana, S.D.V. (2012) Liquid microbial consortium a potential tool for sustainable soil health. J Biofertil Biopestici 3:124. pp.1-9 doi:10.4172/2155-6202.1000124

Purakayastha, T., Chauhan, S., Sasmal, S.and Pathak, S. (2015). Biochar carbon sequestration in soil -A myth or reality? International Journal of Bio-resource and Stress Management. 6: 623-630. 10.5958/0976-4038.2015.00097.4.

Ramezani, M., Riahi Madvar, A., Khaleghi, M. and Hemmati, R. (2015). Isolation and identification of new beneficial bacterial strains from rhizosphere of Citrus sinensis orchards. Progress in Biological Sciences, 5(1): 75-84. doi: 10.22059/pbs.2015.53957

Ramnarain, Y. I., Ansari, A. A. and Ori, L. (2019). Vermicomposting of different organic materials using the epigeic earthworm Eisenia foetida. International Journal Recycle Organic Waste in Agriculture, 8:23-36.

Rana, H., Sharma, K. and Negi, M. (2020). Effect of organic manure and biofertilizers on plant growth, yield and quality of Sweet orange (Citrus sinensis L.). International Journal of Current Microbiology and Applied Sciences, 9: 2064-2070. 10.20546/ijcmas.2020.904.247.

Rawat, J., Saxena, J. and Sanwal, P. (2019). Biochar: A sustainable approach for improving plant growth and soil properties. In Biochar-An imperative amendment for soil and the environment. IntechOpen.pp.1-17 https://doi.org/10.1016/j.scitotenv.2019.134645

Rouiss, H., Cuenca, J., Navarro, L., Ollitrault, P. and Aleza, P. (2017). Tetraploid citrus progenies arising from FDR and SDR unreduced pollen in 4x X 2x hybridizations. Tree Genetics \& Genomes, 13(1), 10.

Saleemi, M., Kiani, M.Z., Sultan, T. Khalid, A. and Mahmood, S. (2017). Integrated effect of plant growth-promoting rhizobacteria and phosphate-solubilizing microorganisms on growth of wheat (Triticum aestivum L.) under rainfed condition. Agric \& Food Secur 6, 46 PP.1-8 https://doi.org/10.1186/s40066-017-0123-7

Shaimaa, M. A. and Massoud, O. N. (2017). Impact of Inoculation with Mycorrhiza and Azotobacter under different $\mathrm{N}$ and $\mathrm{P}$ rates on growth, nutrient status, yield and some Soil characteristics of Washington Navel Orange Trees, Middle East J. Agric. Res, 6 (3): 617638.

Shamseldin, A., El-Sheikh, M. H., Hassan, H. S. A. and Kabeil, S. S. (2010). Microbial biofertilization approaches to improve yield and quality of Washington Navel orange and reducing the survival of nematode in the soil. J. Amer. Sci. 6 (12): 264-271.

Singh, B. P., Hatton, B.J., Singh, B. and Cowie, A. L. (2010). The role of biochar in reducing nitrous oxide emissions and nitrogen leaching from soil. 19th World Congress of soil science, soil solutions for a changing World, Brisbane, Australia, 1-6 Aug 2010.

Suhag, M. (2016). Potential of biofertilizers to replace chemical fertilizers. International advanced research journal in science, engineering and technology, 3(5): 163-167. 
Tadayon, S. M. and Hosseini, S. M. (2020). Effect of spread and shallow irrigation wetted area and application of organic mulch on citrus decline amelioration. Advances in Horticultural Science, 34(2): 213-221.

Tayyab, M., Khalil, F., Ziqin, P., Caifang, Z., Arafat, Y., Rizwan, M., Waheed, S., Tarin, M., Hua, Z., Ahmad, K. and Islam, W. (2018). Biochar: An efficient way to manage low water availability in plants. Applied Ecology and Environmental Research. 16. 10.15666/aeer/1603_2565-2583.

Trinchera, A., Torrisi, B., Allegra, M., Rinaldi, S., Rea, E., Intrigliolo, F. and Roccuzzo, G. (2015). Effects of organic fertilization on soil organic matter and root morphology and density of orange trees. Acta Hortic, 1065: 1807-1814.

Ullah, M.I., Riaz, M., Arshad, M., Khan, A.H., Afzal, M., Khalid, S., Mehmood, N., Ali, S., Khan, A.M., Zahid, S.M.A. and Riaz, M. (2019). Application of Organic Fertilizers Affect the Citrus Leafminer, Phyllocnistis citrella (Lepidoptera: Gracillariidae) Infestation and Citrus Canker Disease in Nursery Plantations. International Journal of Insect Science, 11: $1-5$.

Vives-Peris, V., Molina, L., Segura, A., Gomez-Cadenas, A. and Perez-Clemente, R. M. (2018a). Root exudates from citrus plants subjected to abiotic stress conditions have a positive effect on rhizobacteria. Journal of plant physiology, 228: 208-217.

Vives-Peris, V., Gomez-Cadenas, A. and Perez-Clemente, R. M. (2018b). Salt stress alleviation in citrus plants by plant growth-promoting rhizobacteria Pseudomonas putida and Novosphingobium sp. Plant cell reports, 37(11): 1557-1569.

Wang, M. and Xia, R. (2009). Effects of arbuscular mycorrhizal fungi on growth and iron uptake of Poncirus trifoliata under different pH. Acta microbiologica Sinica. 49: 1374-9.

Wong, H., J. Gao, X. Li, S. Zhang and H. Wang (2015). Nitrate accumulation and leaching in surface and groundwater based on simulated rainfall experiments. PLOS ONE 10(8): 1-18. doi: $10.1371 /$ journal. pone. 0136274

Wu, S., Zhang, Y., Tan, Q., Sun, X., Wei, W., and Hu, C. (2020). Biochar is superior to lime in improving acidic soil properties and fruit quality of Satsuma mandarin. Science of The Total Environment, 714, 136722.

Xiao, J., Hu, C., Chen, Y., Yang, B. and Hua, J. (2014). Effects of low magnesium and an arbuscular mycorrhizal fungus on the growth, magnesium distribution and photosynthesis of two citrus cultivars. Scientia Horticulturae. 177: 14-20. 10.1016/j.scienta.2014.07.016.

Yadav K. K. and Sarka S. (2019). Biofertilizers, impact on soil fertility and crop productivity under sustainable agriculture. Environ. Ecol. 37, 89-93. 